\title{
SPEECH ACTS PREFERENCE IN COMPUTER - MEDIATED INTERCULTURAL COMMUNICATION VIA FACEBOOK MESSENGER: A NETNOGRAPHIC STUDY
}

\author{
Yehezkiel Adhi Nugraha
}

\section{English Teaching Department \\ IKIP PGRI Madiun}

\begin{abstract}
People will not only use language for sharing message but also due to do an action. Through language, people will ask, promise, refuse, greet, invite, thank, and so on. The purpose of this research is to identify the speech acts preference used by Indonesian and Filipino non - native speakers of English via Facebook Messenger. Besides, to identify the similar or different of speech acts preference they used.

The source of data are utterances of conversation in Facebook Messenger. The researcher applies documentation and an observation (reading the book and internet as the references) in collecting the data. After collecting the data, the researcher analyzes the data by focusing the speech acts theory. In order to support the evidence of the result, the researcher needs to describe and compare the high context-cultures and low context-cultures by Hall (1976) and also cultural dimension of Indonesia and Philippines by Hofstede.

The result of the analysis shows that the most speech acts preference used by Indonesian and Filipino non - native speakers of English is direct speech act. Similar and different types of speech acts are found. The similar speech act preferences are found in declarations and representatives. The different speech acts preferences are found in expressives, directives, commissives, direct, and indirect speech acts. The result of this research also shows that the communication of Indonesian and Filipino are included into low contex-cultures. It is contrary with the theory of Hall and Hofstede which shows that Indonesia and Philippines factually should be high context-cultures.
\end{abstract}

Keywords: Speech Acts, Intercultural Communication, CMC, Facebook Messenger, Netnography.

\section{Introduction}

Globalization process is now going on. It is supported by the progress of some well-known discussions such as information, communication, and transportation. Communication is the most evidence of globalization process. People now are available to speak not only by face to face but also through a social media technology. Communication is a process of human interaction. Guirdham (2005: 6) states that communication can be defined 
as the collective and interactive process of generating and interpreting messages. It means that communication describes about the process of human's interactive in getting messages or meanings. Through a social media communication people will be easily to establish a communication with people around the world.

It is called by intercultural communication when there are at least two people with different cultural form making an interaction. The World Bank through Comm GAP describes intercultural communication takes place when individuals influenced by different cultural communities negotiate shared meanings in interaction. It means that the intercultural communication is about sharing the meanings in interaction which done among people who have different cultural communities. People who want to make an intercultural communication will need language as a way to be able to speak with one another. People will not only use language for sharing message but also due to do an action. Through language, people will ask, promise, refuse, greet, invite, thank, and so on. It has been unanimously agreed that each culture will be uniquely to realize the speech acts, and intercultural misscommunication will only appear when the communicators see the uniqueness from the standpoint of their own culture without good willing to understand.

It can be concluded that the differences of culture in a communication, especially intercultural communication will emerge differences of how communicators establish and use the way (speech acts) as a good and acceptable communication. In this study the researcher intends to to identify the speech acts preference used by Indonesian and Filipino non - native speakers of English via facebook messenger on January 2015. Besides to identify the similarity and difference of speech acts preference they used.

\section{Literature Review}

\subsection{Speech Acts}

Speech acts is a branch of linguistics which studies about actual usage of language. Austin (in Geis, 1995: 3) observes speech acts by stating that in saying something has a certain sense and reference, one is normally also doing something other than just saying something, but making a request, as in the case of the sentences of, or making a promise or offer, or an apology, etc. Yule (1996: 47) states that actions performed via utterances are generally called speech acts and, in English, are commonly given more specific labels, such as apology, complaint, compliment, invitation, promise, or request. Meanwhile, Searle (1971: 44) 
asserts that speech acts are characteristically performed in the utterance of sounds or the making of marks.

In the book "How To Do Things with Words", Austin (1962: 101) divides three types of action: (1) Locutionary speech act (an act of saying something). (2) Illocutionary speech act (an act of doing something by saying something). (3) Perlocutionary speech act. The explanation of each type of speech acts are as follows:

\subsubsection{Locutionary Act}

Locutionary act is a speech act which the function is to express something literarily. Austin (in Levinson, 1983: 236) defines locutionary act is the utterance of a sentence with determinate sense and reference. Meanwhile, Yule (1996: 48) states that locutionary act is the basic act of utterance, or producing a meaningful expression.

\subsubsection{Illocutionary Act}

Illocutionary act means doing something through saying something. Austin (1962: 99) asserts "I explained the performance of an act in this new and second as the performance of an 'illocutionary' act, i.e. performance of an act in saying something as opposed to performance of an act of saying something”. Meanwhile Yule (1996: 48) asserts that illocutionary is performed via the communicative force of an utterance. He gives examples of illocutionary type such statement, request, apology, and promise.

\subsubsection{Perlocutionary Act}

Perlocutionary act is a speech act that impact which created by the speaker to the hearer, so that the hearer perform the content of what the speaker said. According to Austin (in Levinson, 1983: 236), perlocutionary act is speech act in saying something with the intent to cause effects, reactions, or in response to actions on the audience by means of uttering the sentence, such effects being special to the circumstances of utterance. Yule (1996: 49) defines perlocutionary act by using illustration, "depending on the circumstance, you will utter on the assumption that the hearer will recognize the effect you intended (for example, to account for a wonderful smell, or to get the hearer to drink some coffee)". Perlocutionary speech act can produce an effect or power of speech to the hearer and make a sense of worry, fear, anxiety, sadness, delight, despair, disappointment, and so on. The example is when someone says "My right hand is itch", supposed the speaker wants to worry the listener. The worry will appear just because the listener thinks that the speaker has a profession as 
a boxer which in everyday life practice to punch the enemy.

Generally, there are five classifications of functions performed by speech acts: declarations, representatives, expressives, directives, and commissives (Yule 1996: 53-54 and Searle in Levinson, 1983: 240). The explanation of the classifications are formulated as follow:

\subsubsection{Declarations}

Declarations are those kinds of speech acts that change the world via utterance. Declarations act effects immediate changes in the institutional state of affairs and which tend to rely on elaborate extra-linguistic institutions (paradigm cases: excommunicating, declaring war, christening, firing from employment).

\subsubsection{Representatives}

Representatives are those kinds of speech acts that state what the speaker believes to be the case or not. It is an act which commits the speaker to the truth of the expressed proposition (paradigm cases: asserting, concluding, etc).

\subsubsection{Expressives}

Expressives are those kinds of speech acts that state what the speaker feels. They express psychological states and can be statements of pleasure, pain, thanking, welcoming, congratulating, likes, dislikes, joy, or sorrow.

\subsubsection{Directives}

Directives are those kinds of speech acts that speakers use to get someone else to do something. In other words, they express what the speaker wants.

\subsubsection{Commissives}

Commissives are those kinds of speech acts that the speakers use to commit themself to some future actions. They express what the speaker intends. They are promises, threats, refusals, pledges, and so on. Commissives can be performed by the speaker alone, or when the speaker as a group member.

The other type of speech acts are direct and indirect speech act. Yule (1996: 54) assumes that there is an easily recognized relationship between the three structural forms (declarative, interrogative, imperative) and the three general communicative functions (statement, question, command/request). The explanation is illustrated in examples as follow:

Examples:

a. You wear a seat belt

(declarative)

b. Do you wear a seat belt?

(interrogative)

c. Wear a seat belt!

(imperative)

By looking the example above, it can be defined that each structure of speech act 
will has a different function in process of uttering something. Explicitly, the definition of direct and indirect speech act has been stated by some experts as follow:

\subsubsection{Direct speech act}

Yule (1996: 54) states, "Whenever there is a direct relationship between a structure and function, we have a direct speech act". It means that an utterance will be a direct speech act if the structure and the function is purposed directly.

\subsubsection{Indirect speech act}

Yule (1996: 55) states, "Whenever there is an indirect relationship between a structure and function, we have an indirect speech act". Whereas Verschueren (in Griffiths 2006: 149) asserts, "When a sentence type is used in the performance of speech acts different from their default kind, we have what are called indirect speech acts". It means that an utterance will be an indirect speech act if the structure and the function is purposed indirectly but the meaning is to be done as the command, though sometimes the structure is like request or question.

\subsection{Intercultural Communication based on}

\section{Hall and Hosftede}

Hall (1976: 91) divides culture into two dimensions, high-context and lowcontext cultures. This theory is based on individualism and collectivism. Low contex-cultures is found in the people who follow individualism culture, whereas high contex-cultures is found in the people who follow collectivism culture. High or low context cultures are characterized by high or low the context of communication. "A high-context communication or message is one in which most of the information is either in the physical context or internalised in the person, while very little is in the coded, explicit, transmitted part of the message. On the other hand, a lowcontext communication is just the opposite; i.e. the mass of the information is vested in the explicit code" (Hall, 1976: 91). It means that high context-cultures are characterized by a high context communication which mostly contains implicit message and indirect. The actual message is hidden in nonverbal behavior such as: tone of voice, hand gestures, body posture, facial expression, and so on. Meanwhile, the low context-cultures are marked by low context communication which verbal messages and explicit, direct speech, straightforward, and forthright. In the book of Beyond Cultures, Hall also identifies that Western/Northern European cultures has low-context cultures while the cultures in the Eastern Mediterranean, Asia and Latin America are identified as highcontext cultures. It means that Indonesia and Philippines are included into highcontext cultures. It is supported with 
Hofstede's cultural dimension. Hofstede through Hofstede Centre (http://geerthofstede.com/) compares the cultural country dimension between Indonesia and Philippines into basic value dimensions: powerdistance, individualism / collectivism, masculinity / femininity, uncertaintyavoidance, and long/short term orientation. The dimensions are measured on a scale from 0 to 100 . Although his country scores were originally produced in the early 1970s, many replications of Hofstede's study on different cultures have proved that his data are still valid.

The Hofstede's score in three of five basic value dimensions give proof that Indonesia and Philippines are included into high context-cultures. In the power distance dimension, Indonesia and Philippines similarly scores high which Indonesia scores 78 while Philippines scores 94. It means that Indonesia and Philippines are similarly included into high power distance which same meaning to high-context cultures. Hofstede describes that this dimension has characteristics which refer to high context-cultures: communication is indirect and negative feedback hidden, co-workers would expect to be clearly directed by the boss or manager (it is the classic Guru-Murid kind of dynamic that applies to Indonesia). In Philippines, hierarchy in an organization is seen as reflecting inherent inequalities, centralization is popular, subordinates expect to be told what to do and the ideal boss is a benevolent autocrat.

Hofstede describes two definitions in individualism dimension. They are about individualist and collectivist. In individualist societies people are supposed to look after themselves and their direct family only. In Collectivistic societies, people belong to 'in groups' that take care of them in exchange for loyalty. In this dimension, Indonesia and Philippines are categorised as low score which Indonesia scores 14 while Philippines scores 32. It means that both Indonesia and Phlippines are collectivistic society. By this proof, Indonesia and Philippines are included into high context-cultures.

Uncertainty avoidance dimension is described by Hofstede as people's way to deal the future which never be known. His illustration is stated in interrogative form whether people should try to control the future or just let it happen. This ambiguity brings an anxiety and different cultures have learnt to deal with this anxiety in different ways. It can be concluded that in each different cultures will have different way to express the kinds of anxiety. In this dimension Indonesia scores 48 while Philippines scores 44. It means that they belongs to low for avoiding uncertainty. 
Hofstede (http://geert-hofstede.com/) states there is a strong preference in Indonesia toward the Javanese culture of separation of internal self from external self. It is proved when a person is upset, it is habitual for the Indonesian not to show negative emotion or anger externally. They will keep smiling and be polite, no matter how angry they are inside. Filipino society maintains a more relaxed attitude in which practice counts more than principles and deviance from the norm are more easily tolerated. It means that they have a relaxed attitude to other society and anything wrong can be tolerated well. This proves that Indonesia and Philippines have same way to make an interaction by showing relaxed attitude and covering main feeling by keep smiling and be polite. It is similar with indirect communication which people do not send the meaning of saying directly. It means that Indonesia and Philippines are included into high context-cultures.

\subsection{CMC and Facebook Messenger}

It is a recently exchange that communication is not always go through face to face way. There is Computer Mediated Communication or brevity called CMC which has been a popular way in building such interaction or communication. December (1996) through the web official defines Computer Mediated Communication (CMC) is the process by which people create, exchange, and perceive information using networked telecommunications systems (or nonnetworked computers) that facilitate encoding, transmitting, and decoding messages. Whereas, Berge and Collins (1995: 6) in (http://www.december.com) state "CMC describes the ways we humans use computer systems and networks to transfer, store, and retrieve information, but our emphasis is always on communication". It means that actually the main purpose of CMC is communication itself. The example of popular applications nowadays, such as Yahoo Messenger, MSN Messenger, Blackberry Messenger, Whatsapp, Facebook Messenger, and so on.

Facebook Messenger is part of Facebook actually. It is now a social media chatting application which syncronized to Facebook account. According to Zhang (Facebook Engineering), facebook messenger is a new stand-alone messaging app that enables people to send messages one on one or to groups of friends. HTCcooperation (2013: 28) states, "Use the Facebook Messenger application to start private conversations with your friends on Facebook". It means that the function of Facebook Messenger is to chat personally with friends on Facebook. As the definition about computer mediated 
communication before, chatting is included to kind of CMC. It means that Facebook Messenger is included to CMC.

\section{Approach and Type of Research}

This research is included to qualitative research. Qualitative research is research which has characteristic that the data is analyzed into description. "As you considered all of this, you were doing what all qualitative researchers do when they think about, or analyze and interpret, their data, which is to reflect on and explore what they know, search for patterns, and try to create a full and rich understanding of the research context" (Heigham and Croker, 2009: 3-4). It means that qualitative research focuses on describing and interpreting what facts in a field are happening. This research reveals not only about how the speech acts preference that used by both of Indonesian and Filipino is being described, but also how the cultural dimension of both Indonesia and Philippines are. Viewing those reasons, the researcher uses content analysis and also netnographic study as the research method in this research.

In this research, the researcher is becoming an observer and also taking part directly in the process of intercultural communication through Facebook Messenger. The data is taken from the conversation between Indonesian and Filipino non - native speakers in Facebook Messenger, on January 2015. The researcher also looks for some information references about country comparison of participants that helps the researcher in revealing the cultural dimension of Indonesia and Philippines.

The researcher uses documentation as the technique of collecting data. The data is analyzed by content analysis. Krippendorff (2004: 18) defines content analysis is a research technique for making replicable and valid inferences from texts (or other meaningful matter) to the contexts of their use. Meanwhile, Holsri (in Berg, 2001: 240) states content analysis is any technique for making inferences by systematically and objectively identifying special characteristics of messages. From this perspective, photographs, videotape, or any item that can be made into text are amenable to content analysis. Ary et al., (2010: 457) assert that content or document analysis is a research method applied to written or visual materials for the purpose of identifying specified characteristics of the material.

However, the researcher assumes that this research relates to the intercultural communication. The study seeks the understanding of relationship between culture and communication, with culture 


\begin{tabular}{|c|c|c|c|c|c|}
\hline No & $\begin{array}{c}\text { Types of } \\
\text { Speech Acts }\end{array}$ & INA & $\begin{array}{l}\text { In } \\
\text { Per/cent }\end{array}$ & FLP & $\begin{array}{c}\text { In } \\
\text { Per/cen } \\
\mathbf{t}\end{array}$ \\
\hline 1 & Declarations & 0 & $0 \%$ & 0 & $0 \%$ \\
\hline 2 & $\begin{array}{l}\text { Representative } \\
\mathrm{S}\end{array}$ & 7 & $10 \%$ & 6 & $10 \%$ \\
\hline 3 & Expressives & 11 & $16 \%$ & 12 & $19 \%$ \\
\hline 4 & Directives & 14 & $20 \%$ & 9 & $15 \%$ \\
\hline 5 & Commissives & 3 & $4 \%$ & 4 & $6 \%$ \\
\hline 6 & Direct & 26 & $38 \%$ & 22 & $35 \%$ \\
\hline \multirow[t]{2}{*}{7} & Indirect & 8 & $12 \%$ & 9 & $15 \%$ \\
\hline & Total & 69 & $100 \%$ & 62 & $100 \%$ \\
\hline
\end{tabular}

referring to the shared beliefs, values, concepts, practices, and attitudes of a specific group of people is called by etnography (Ary et al., 2010: 459). It means the researcher should use kind of etnographic study to reveal and analyze how cultural difference (of Indonesian and Filipino) affects intercultural communication which they do by Facebook messenger, online social media application.

Related to the some definitions about content analysis and study of netnography above, the researcher deals to use content analysis and netnography as the research method.

\section{Result and Discussion}

Based on the data analysis, the speech act preferred by Indonesian and Filipino non-native speakers of English is direct speech act. The researcher presents the result of data analysis into a distribution table of comparison in order to know how similar and different the speech acts preference used by Indonesian and Filipino. The researcher uses abbreviations in the table which INA are used for Indonesian and FLP for Filipino. The table is presented below:

Table 4.1 Distribution of The Speech Acts Preference used by Indonesian and Filipino non Native of English

They prefer to use direct speech acts than indirect speech acts. Indonesian uses direct speech acts for 26 times (38\%) and Filipino uses it for 22 times (35\%). Meanwhile, Indonesian uses indirect speech acts for only 8 times (12\%) and Filipino uses it for only 9 times (15\%). It means that direct speech acts are dominant preferred speech act used by both Indonesian and Filipino in the intercultural communication via Facebook Messenger. The researcher has an assumption that the result of this research shows their communication is included into lowcontext cultures. It is contrary with the theory which developed by Hall (1976: 91) about high and low-context cultures or Hofstede (http://geert-hofstede.com/) about power distance dimension, which shows that Indonesia and Philippines are included into high-context cultures.

The researcher assumes exactly the difference between the result of this 
research (the communication of Indonesian and Filipino are included into low contextcultures) and the theory of Hall and Hofstede (Indonesia and Philippines factually should be high context-cultures) are caused by some points. Firstly, the culture of Indonesia and Philippines has changed. The research before which done by researchers in comparison with the research in nowadays era proves that there is a change of culture of Indonesia and Philippines in this modern era. It can be seen in the context of communication which people are now easy to be able in making an intercultural communication through social media communication. Secondly, the result of this research shows that youth interlocutors (Indonesian and Filipino) prefer to communicate directly than must be not straightforward (talking aroundly). Besides, the interlucators in the conversation are university students. Finally, based on theory of Hall and the evidences above, it can be concluded that both Indonesian and Filipino are exposed to western cultures which prefer to have low context-cultures than high contextcultures.

\section{Conclusion}

Speech acts preference used by Indonesian and Filipino non - native speakers of English in the conversation via Facebook Messenger is direct speech act. The researcher finds the types of speech acts which used in the conversation. They are representatives, expressives, directives, commissives, direct, and indirect speech acts. There is declarations speech acts never used in the conversation.

In this research, the researcher finds the similarities and differences of speech acts preference used by Indonesian and Filipino non-native of English. The similar speech acts preference are found in declarations and representatives. The different speech acts preference are found in expressives, directives, commissives, direct, and indirect speech acts. The communication of Indonesian and Filipino is included into low-context cultures.

\section{References}

Ary, D. (2010). Introduction to Research in Education. Belmont, Calif, CA: Thomson/ Wadsworth.

Austin, J. (1962). How to Do Things with Words. Cambridge: Harvard University Press.

Berg, B. (2001). Qualitative Research Methods for The Social Sciences. Boston: Allyn and Bacon.

Berge, Z., and Collins, M. (1995).

Computer-Mediated 
Communication and The Online

Classroom od Distance Learning.

(http://www.december.com

Retrieved on March 9th, 2015).

CommGAP. Intercultural Communication. (www.worldbank.org/commgap, Retrieved on March 9th, 2015).

December. (1995). Computer - Mediated Communication and the Online Classroom in Distance Learning (http://www.december.com/cmc/ma g/1995/apr/berge.html/ Volume 2, Number 4/ April 1, 1995/ Page 6, Retrieved on March 23th 2015).

Geis, M. (1995). Speech Acts and

Conversational Interaction.

Cambridge, New York: Cambridge University Press.

Hall, E. (1976). Beyond culture. Garden City, N.Y.: Anchor Press.

HTC Corporation. (2013). Your HTC First $^{\mathrm{TM}}$ User Guide. HTC Corporation

Kozinets, R. (2002). The Field Behind The Screen: Using Netnography For Marketing Research In Online
Communities. Journal of Marketing Research, XXXIX(39), 61-72.

Kozinets, R. (2010). Netnography: Doing Ethnographic Research Online. Los Angles, USA: SAGE. ISBN: 978-184860-645-6. Field Methods,38, 11 (http://www.sagepub.com, Retrieved on March 10th, 2015).

Krippendorff, K. (2004). Content analysis: An Introduction to Its Methodology. (2nd ed). Beverly Hills: Sage Publications.

Levinson, S. (1983). Pragmatics (1st ed). Cambridge: Cambridge University Press.

Searle, J. (1971). The Philosophy of Language. London: Oxford University Press.

The Hofstede Centre. (http://geerthofstede.com/indonesia.html, Retrieved on March 23th 2015).

Yule, G. (1996). Pragmatics. (1st ed). Oxford, New York: Oxford University Press. 